\title{
Semiconductors as sensitisers for the radical addition of tertiary amines to electron deficient alkenes
}

\author{
Siniša Marinković and Norbert Hoffmann \\ Equipe Photochimie, Laboratoire de Réactions Sélectives et Applications, UMR 6519, \\ CNRS et Université de Reims Champagne-Ardenne, UFR Sciences \\ BP 1039, F-51687, Reims, Cedex 02, France.
}

\begin{abstract}
Using heterogeneous photocatalysis, the radical addition of tertiary amines with electron deficient alkenes can be performed in high yields (up to 98\%) and high facial diastereoselectivity. The photochemical induced electron transfer process initiates the radical chain reaction and inorganic semiconductors like $\mathrm{TiO}_{2}$ and $\mathrm{ZnS}$ were used. According to the proposed mechanism, the reaction takes place at the surface of the semiconductor and the termination step results from an interfacial electron transfer from the conduction band to the oxoallyl radical intermediate. Frequently, semiconductors are used for the mineralisation of organic compounds in wastewater. However, in this case, they are used in organic synthesis. The process can be performed in a convenient way and is particularly interesting from the ecological and economical point of view. No previous functionalization of the tertiary amines is necessary for $\mathrm{C}-\mathrm{C}$ bond formation. Further on, the amines are used both as reactant and as solvent. The excess is recycled by distillation and the inexpensive sensitiser can be easily removed by filtration. In this way, products of high interest for organic synthesis are obtained by a diastereoselective radical reaction.
\end{abstract}

\section{INTRODUCTION}

Radical reactions have become an important tool in organic chemistry, but the control of reactivity and selectivity still needs considerable efforts [1]. Among radicals having a nucleophilic character, $\alpha$-aminoalkyl radicals seem very attractive for the addition to electron deficient alkenes. These radicals are used for the synthesis of nitrogen containing compounds [2]. Tertiary amines are easily oxidized and radical-cations are obtained. These intermediates yield $\alpha$-aminoalkyl radicals via the deprotonation in the $\alpha$-position of nitrogen. Despite their synthetic potential, low chemical yields have been reported for the addition of $\alpha$-aminoalkyl radicals to $\alpha, \beta$-unsatured esters and ketones [3]. The formation of oligomers and degradation products are limiting factors for this reaction, either for the photochemical [4] or for the ground state reactions in the presence of peroxides [5].

Recently, we described an efficient procedure involving a photochemical electron transfer to initiate the intermolecular radical addition of tertiary amines to electron deficient alkenes [6, 7]. This method uses homogeneous photocatalysis with electron donor substitued aromatic ketones as sensitisers. The products have been isolated with yields up to $94 \%$ and a quantum yield of $\Phi=4$ indicating a radical chain process. The high yields obtained with these sensitisers, which react in a charge transfer excited state, indicate that a photochemical electron transfer followed by a deprotonation step can be an efficient pathway for the generation and the addition of $\alpha$-aminoalkyl radicals. Moreover, electron donating substituents in the para position of the aromatic ring stabilize the ketyl radical intermediate and avoid coupling products involving the sensitiser. Therefore, under homogeneous photocatalysis, only catalytic amounts of sensitiser ( $0.1 \mathrm{eq})$ were used. At the end of the reaction, it could be recovered up to $80 \%$. Under the same reaction conditions, radical tandem reactions could also be carried out efficiently [8].

In order to develop a new approach for these reactions under heterogeneous photocatalysis, we tested inorganic semiconductors like $\mathrm{TiO}_{2}$ and $\mathrm{ZnS}$ as sensitisers [14].

Photochemical reactions with semiconductors were studied, for instance, for the detoxification of wastewater $[9,10]$, oxidations and reductions, light energy harvesting [11] or in the context of organic synthesis $[12,13]$. During the photochemical reaction, an electron is transferred from the valence band into the conduction band. We wondered whether the electron hole $\mathrm{h}^{+}$of the valence band could be filled by an interfacial electron transfer from a reductive species such as a tertiary amine. In this way, a radical-cation might be produced and after deprotonation a nucleophilic $\alpha$-aminoalkyl radical should be obtained.

\section{RESULTS AND DISCUSSION}

We started our investigations by irradiating a suspension of $\mathrm{SiC}$, $\mathrm{ZnS}$ or $\mathrm{TiO}_{2}$ (anatase $99 \%$ ) and a solution containing $(5 R)$-menthyloxy-2[5H]furanone $\mathbf{1 a}$ and $N$-methylpyrrolidine $2 \mathbf{a}$ in acetonitrile. The starting amount of semiconductor in the mixture was 0.1 equivalent with respect to $1 \mathrm{a}$ (Table 1 , entries 1-3). 
Table 1. Reaction of (5R)-menthyloxy-2[5H]furanone 1a with $N$-methylpyrrolidine 2a under different reaction conditions.

\begin{tabular}{|c|c|c|c|c|c|c|c|c|}
\hline & $1 a$ & & $2 a$ & & $3 a$ & & $4 a$ & \\
\hline Entry & $\begin{array}{c}\text { Semiconductors } \\
(\mathrm{mg} / 150 \mathrm{~mL})\end{array}$ & $\begin{array}{c}\mathrm{c}(\mathbf{1 a}) \\
{\left[\mathrm{mol} \cdot \mathrm{L}^{-1}\right]}\end{array}$ & $\begin{array}{c}\mathrm{c}(\mathbf{2 a}) \\
{\left[\mathrm{mol} \cdot \mathrm{L}^{-1}\right]}\end{array}$ & $\begin{array}{c}\text { Irradiation } \\
\text { time }[\mathrm{h}]\end{array}$ & $\begin{array}{c}\text { Conversion } \\
{[\%]}\end{array}$ & $\begin{array}{c}\text { Yields }^{(b)}(3 a) \\
{[\%]}\end{array}$ & $\begin{array}{c}\text { Yields }^{(b)}(4 a+5 a) \\
{[\%]}\end{array}$ & $\begin{array}{c}\text { Ratio } \\
\mathrm{c}(4 \mathbf{a}) / \mathrm{c}(5 \mathbf{a})\end{array}$ \\
\hline 1 & $\mathrm{TiO}_{2}(12)^{(\mathrm{a})}$ & $10^{-2}$ & $4 \times 10^{-1}$ & 9 & $59 \%$ & n.d. & 25 & $47 / 53$ \\
\hline 2 & $\operatorname{ZnS}(15)^{(\mathrm{a})}$ & $10^{-2}$ & $4 \times 10^{-1}$ & 9 & 68 & n.d. & 28 & $45 / 55$ \\
\hline 3 & $\operatorname{SiC}(6)^{(a)}$ & $10^{-2}$ & $4 \times 10^{-1}$ & 8 & - & - & - & - \\
\hline 4 & $\mathrm{TiO}_{2}(12)$ & $10^{-2}$ & 4.8 & 2.25 & 100 & 8 & 51 & $45 / 55$ \\
\hline 5 & $\mathrm{TiO}_{2}(30)$ & $10^{-2}$ & 4.8 & 1 & 100 & 14 & 54 & $42 / 58$ \\
\hline 6 & $\mathrm{TiO}_{2}(12)$ & $10^{-2}$ & Solvent & 2.5 & 100 & - & 53 & $45 / 55$ \\
\hline 7 & $\mathrm{TiO}_{2}(12)$ & $5 \times 10^{-2}$ & 4.8 & 4 & 37 & 32 & 62 & $45 / 55$ \\
\hline 8 & $\mathrm{TiO}_{2}(30)$ & $5 \times 10^{-2}$ & 4.8 & 4 & 52 & 19 & 67 & $45 / 55$ \\
\hline 9 & $\mathrm{TiO}_{2}(12)$ & $5 \times 10^{-2}$ & Solvent & 2.5 & 73 & - & 90 & $45 / 55$ \\
\hline 10 & $\mathrm{TiO}_{2}(30)$ & $5 \times 10^{-2}$ & Solvent & 2.5 & 48 & - & 85 & $45 / 58$ \\
\hline 11 & $\mathrm{TiO}_{2}(12)$ & $10^{-1}$ & Solvent & 2.5 & 50 & - & 39 & $45 / 55$ \\
\hline
\end{tabular}

n.d.: not determined.

(a) The amount of semiconductor corresponds to 0.1 equivalent with respect to 1 a.

(b) Yields of isolated products and based on the conversion of $\mathbf{1 a}$.

Low conversion rates were observed for $\mathrm{TiO}_{2}$ and $\mathrm{ZnS}$, while no transformation could be detected for SiC. However, these results indicated that the radical reaction is possible. The yields based on conversion were rather low. After nine hours of irradiation, a lot of degradation and side products were detected. In order to optimize the reaction, different conditions have been tested using only $\mathrm{TiO}_{2}$ as sensitiser (Table 1, entries 4-11). Much faster conversions were observed when the concentration of 2a was increased (Table 1, entries 4, 5, 7 and 8) and the best results were obtained when the amine was used as solvent (Table 1, entries 9 and 10). In many cases (entries 4, 5, 7 and 8), a side product 3a resulting from the Michael addition of pyrrolidine to 1a was isolated. For a given concentration of $\mathbf{2 a}$ and a constant amount of semiconductor, yields of 3a increased with increasing the concentration of 1 a (Table 1 , entries 4 , 7 and 5,8). Further on, we concluded that the reaction of demethylation of $2 \mathbf{a}$ involves the presence of (5R)-menthyloxy-2[5H]furanone $\mathbf{1 a}$ and the sensitiser as well. Fortunately, the side reaction was suppressed when the tertiary amine was used as the solvent. The best yields of $4 \mathbf{a}$ and $5 \mathbf{a}$ were obtained when the starting concentration of the electron deficient alkene was $5 \times 10^{-2} \mathrm{~mol} \cdot \mathrm{L}^{-1}$ (Table 1 , entry 9 ). For lower concentrations of $1 \mathrm{a}$, the degradation reactions with $\mathrm{TiO}_{2}$ could explain the lower yields of isolated products (Table 1 , entry 6). We noticed that a higher starting concentration of 1a (Table 1, entry 11) decreased the yield, probably due to polymerization of the alkene. Further on, the conversion rate depended on the amount of sensitiser (Table 1, entries 9 and 10). Under heterogeneous conditions, higher amounts of semiconductor $\left(\mathrm{TiO}_{2}\right.$ : $12 \mathrm{mg} / 150 \mathrm{~mL}$ ) lead to an important diffusion of light and consequently lower conversion rates.

Under the optimized conditions (Table 1, entry 9), the reaction was carried out with different semiconductors (Table 2, entries 1-3). High yields (up to 97\%) were obtained in the cases of $\mathrm{TiO}_{2}$ and $\mathrm{ZnS}$. When $\mathrm{SiC}$ was used, the reaction was significantly less efficient. In all cases, the facial diastereoselectivity was high and the attack occurred anti with respect to menthyloxy substituent. Unfortunately, little selectivity was observed for the asymmetric carbon in the $\alpha$-position of the nitrogen. Two diastereoisomers $4 \mathbf{a}$ and 5 a were obtained in a ratio of about $45 / 55$. Under these conditions using $\mathrm{TiO}_{2}$ as sensitiser, $N$-tert-butylpyrrolidine $\mathbf{2 b}$ was added to 1a with the same efficiency and the same yield (Table 2, entry 4).

The reaction of various $\alpha, \beta$-unsatured esters with $N$-methylpyrrolidine $\mathbf{2 a}$ was also examined under the optimized conditions (Table 3). Generally, for the electron deficient alkenes $\mathbf{1 b}$-d, high conversion rates and high yields were observed. However, in the case of lactone 1e possessing an additional substituent in the 4 position, the conversion rate was low. A low reac- 
Table 2. Reaction of (5R)-menthyloxy-2[5H]furanone 1a with $N$-methylpyrrolidine 2a and tert-butylpyrrolidine $2 \mathbf{b}$ and different semiconductors (S.C.); 0.02 mol equivalent of semiconductor with respect to 1a was added.

\begin{tabular}{|c|c|c|c|c|c|c|}
\hline & $\begin{array}{l}\mathrm{O}^{\prime \prime \prime O M e n}+ \\
\mathbf{1 a} \\
5 \times 10^{-2} \mathrm{M}\end{array}$ & $\begin{array}{c}\mathrm{N} \\
\mathrm{l} \\
\mathrm{R} \\
2 \mathrm{a}, \mathbf{b} \\
\text { Solvent }\end{array}$ & $\begin{array}{c}\text { S.C. } \\
(0,02 \text { eq })\end{array}$ & $4 a, b$ & $5 a$, & \\
\hline Entry & $\begin{array}{c}\text { Semiconductors } \\
(\mathrm{mg} / 150 \mathrm{~mL})\end{array}$ & $\mathrm{R}^{(\mathrm{a})}$ & $\begin{array}{c}\text { Irradiation } \\
\text { Time }[\mathrm{h}] \\
\end{array}$ & $\begin{array}{c}\text { Conversion } \\
{[\%]} \\
\end{array}$ & $\begin{array}{l}\text { Yields }^{(b)} \\
(4+5)[\%]\end{array}$ & $\begin{array}{c}\text { Ratio } \\
\mathrm{c}(4) / \mathrm{c}(5)\end{array}$ \\
\hline 1 & $\mathrm{TiO}_{2}(12)$ & $\mathrm{Me}$ & 2.5 & 73 & 90 & $45 / 55$ \\
\hline 2 & ZnS (15) & $\mathrm{Me}$ & 2.5 & 55 & 97 & $44 / 56$ \\
\hline 3 & $\operatorname{SiC}(6)$ & $\mathrm{Me}$ & 5 & 53 & 72 & $47 / 53$ \\
\hline $4^{(\mathrm{c})}$ & $\mathrm{TiO}_{2}(12)$ & $t-\mathrm{Bu}$ & 3.5 & 83 & 88 & $45 / 55$ \\
\hline
\end{tabular}

(a) $2 \mathrm{a}: \mathrm{R}=\mathrm{Me}, \mathbf{2 b}: \mathrm{R}=t$-Bu.

(b) Yields of isolated products and based on the conversion of $\mathbf{1 a}$.

(c) The starting concentration of 1 a was $10^{-2} \mathrm{~mol} \cdot \mathrm{L}^{-1}$.

Table 3. Reaction of different $\alpha, \beta$-unsatured esters with $N$-methylpyrrolidine $2 \mathbf{2}$ as solvent under different conditions; $0.02 \mathrm{~mol}$ equivalent of semiconductor $\left(\mathrm{TiO}_{2}, 12 \mathrm{mg} / 150 \mathrm{~mL}\right.$ ) with respect to $\mathbf{1 b}-\mathbf{e}$ was added.

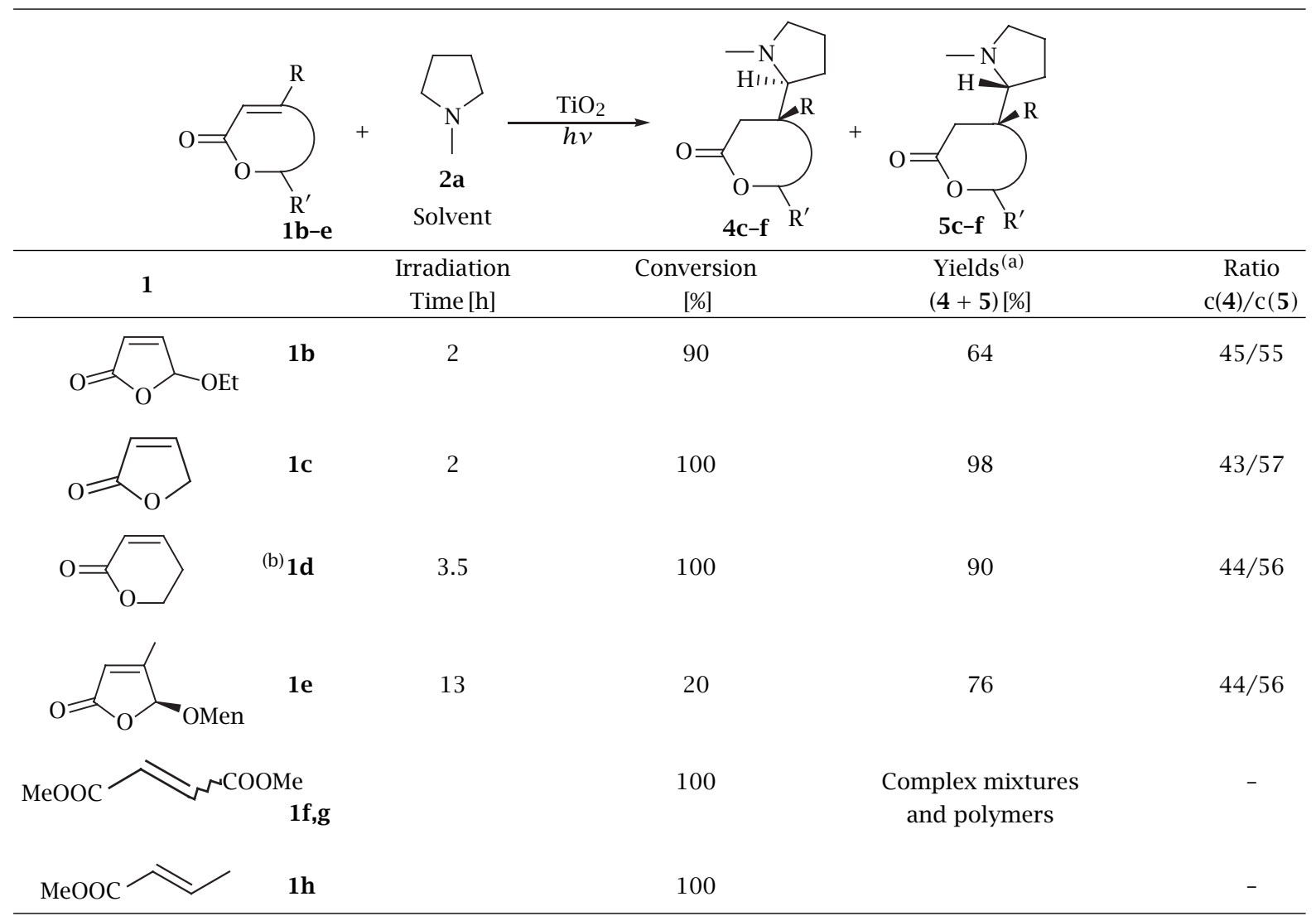

(a) Yields of isolated products and based on conversion of 1.

(b) The starting concentration was $10^{-2} \mathrm{~mol} \cdot \mathrm{L}^{-1}$.

tivity of $\beta$-disubstitued- $\alpha, \beta$-carbonyls compounds was also observed when homogeneous reaction conditions were applied [7]. It has to be noted that somewhat lower yields were obtained with lactones $\mathbf{1 b}$ and $\mathbf{1 e}$ possessing acetal groups. This labile functional group might favor degradation reactions. Furthermore, steric hindrance for the radical attack is more important. For malonic, fumaric and crotonic derivates $\mathbf{1 f}-\mathbf{h}$, complex 
mixtures and polymerization reactions were observed even at a low concentrations of $1\left(10^{-2} \mathrm{~mol} \cdot \mathrm{L}^{-1}\right)$.

In order to explain these results, we propose the mechanism depicted in Scheme 1. The main processes are represented outside the frames. During the photochemical excitation, an electron is transferred from the valence band into the conduction band $[15,17]$. After the charge-carrier generation by a photon, other primary processes can occur in the semiconductor (i.e., charge-carrier trapping at the surface of the semiconductor or in the bulk, charge-carrier recombination) $[10,16]$. In a heterogeneous photocatalysis system, photoinduced molecular transformations or reactions take place at the surface of the semiconductor particle [17]. During the initiation (oxidation) and the termination (reduction), the amine 2a (respectively the alkene 1a) should be adsorbed at the surface. The detailed mechanistic steps at the surface are represented in frames.

The resulting electron hole $\mathrm{h}^{+}$or the trapped hole $\mathrm{h}^{+}$tr (hole trapping: $10 \mathrm{~ns}$ ) can be filled by an interfacial electron transfer from the adsorbed amine $\mathbf{2 a}$. In this way, the radical-cation 14 is generated which after deprotonation afford the $\alpha$-aminoalkyl radical 8 . Due to their acido-basic properties, titanol groups at the surface may support the deprotonation [10, 17]. This deprotonation is kinetically controlled and lead to the cyclic $\alpha$-aminoalkyl radical [18]. $\alpha$-aminoalkyl radicals have the nitrogen lone pair and the singly occupied carbon orbital in anticoplanar orientation. Moreover, the quasiequatorial position of these orbitals in the cycle leads to the most stable $\alpha$-aminoalkyl radical [19]. Therefore, no reaction is observed at the methyl group. The same selectivity and the high yields observed, as in the case of the homogeneous photocatalysis, lead us to conclude that the initiation step occurred at the surface via an interfacial electron transfer followed by a deprotonation. It has been reported that $\mathrm{CO}, \mathrm{CO}_{2}$, and phtalic esters interact with oxygen vacancies at the surface of $\mathrm{TiO}_{2}[10,17]$. Moreover, these defect sites can trap electrons from the conduction band $\left(\mathrm{Ti}^{3+}\right.$ sites).We suppose that the carbonyl group of 1a could interact (be adsorbed) like these compounds (Scheme 1). The radical $\mathbf{8}$ can be added to 1a, leading to the oxoallyl radical 9 adsorbed at the surface (Scheme 1). These intermediates are known to be easily reducible [20]. Therefore, the interfacial back electron transfer occurs to generate the anion 12. Products $4 \mathbf{a}$ and $5 \mathbf{a}$ are obtained after the quenching of $\mathbf{1 2}$ with the adsorbed proton. Consequently, oxidation and reduction steps at the surface of the semiconductor are coupled.

As it was previously reported, for many reactions catalysed by semiconductors, the reactions in solution seem to be less important. In our cases, no products resulting from termination steps in solution (radical dimerisation, ... c) could be detected. Further on, the conversion rate is very low compared to the reaction in homogeneous photocatalysis possessing high quantum yields. Nevertheless, quantitative yields are obtained. Furthermore, no side reaction resulting from an interfacial electron transfer from the conduction band has been observed (e.g. partial reduction of 1a). The most reasonable explanation for this result is that the electron reduces the oxoallyl 9 at the surface which leads to the formation of the target products $4 \mathbf{a}, \mathbf{5 a}$.

When $\mathrm{TiO}_{2}$ was used as sensitiser for the addition of $N$-methylpiperidine 2c, only a slow reaction was observed and product 6 , resulting from a Michael addition of piperidine to 1a was isolated (Table 4, entry 1). The corresponding addition of pyrrolidine observed as side reaction of the amine $\mathbf{2 a}$ was much less efficient and took place only under certain conditions (Table 1 , entries 4, 5, 7 and 8). Due to the lower reactivity of the corresponding $\alpha$-aminoalkyl radicals derived from $N$-methylpiperidine, the oxidation of these radicals became competitive and demethylation occurred [21]. Even under strictly anhydrous conditions, this side reaction took place (Table 4, entry 2). However, when the concentration of compound 1a was reduced, the radical addition could be observed and product 7 was isolated in moderate yield (Table 4, entry 3 ), while the formation of 6 decreased. These results indicate that 1a or more probably the oxoallyl radicals 9, 11 might participate in the demethylation process (Scheme 2, path 1) via the oxidation of radicals $\mathbf{8 , 1 0}$ to $\mathrm{A}$ at the surface of the semiconductor. A tautomeric equilibrium of the iminium ions A and B was established [21] and the nucleophilic attack on the methylene iminium group led to piperidine (respectively pyrrolidine). The secondary amines added efficiently to 1 a to yield 6 (respectively 3a) [22]. However, oxidations of $\alpha$-aminoalkyl radicals by excited $\mathrm{TiO}_{2}$ were also possible (Scheme 2, path 2). Therefore, we searched to diminish the twoelectron oxidation by changing the semiconductor (Table 4, entry 4). When ZnS was used, only product 7 could be isolated. This semiconductor might be less oxidative $\left(\mathrm{E}_{\mathrm{OX}}\left(\mathrm{TiO}_{2}\right)=+2.5 \mathrm{~V}_{(\mathrm{NHE})}\right.$ vs $\left.\mathrm{E}_{\mathrm{OX}}(\mathrm{ZnS})=+1.8 \mathrm{~V}_{(\mathrm{NHE})}\right)$ [23] due to the higher energy level of its valence band edge and its surface properties. Despite the more rapid conversion, the yield of desired product 7 remained low.

With $N$-methylpiperidine 2c, a decrease in the efficiency and an increase in the stereoselectivity with the formation of only one isomer 7 , were observed. In this case, the configuration of the chiral centre in the $\alpha$-position of the nitrogen was controlled. The better stereoselectivity observed with the amine $2 \mathrm{c}$ can be explained on the basis of the steric interactions developed in the transition states leading to the two possible stereoisomers [7].

Under the optimized conditions, acyclic amines like triethylamine $\mathbf{2 d} \mathrm{d}, \mathrm{N}$-dimethylisopropylamine $\mathbf{2 e}$ were unreactive with $\mathrm{TiO}_{2}$ and $\mathrm{ZnS}$ as sensitisers. The $\alpha$-aminoalkyl radicals derived from amines $\mathbf{2 d}$, e were less reactive due to the free rotation around the $\mathrm{C}-\mathrm{N}$ bond. In the case of $N$-ethyldiisopropylamine $2 \mathbf{f}$, the 


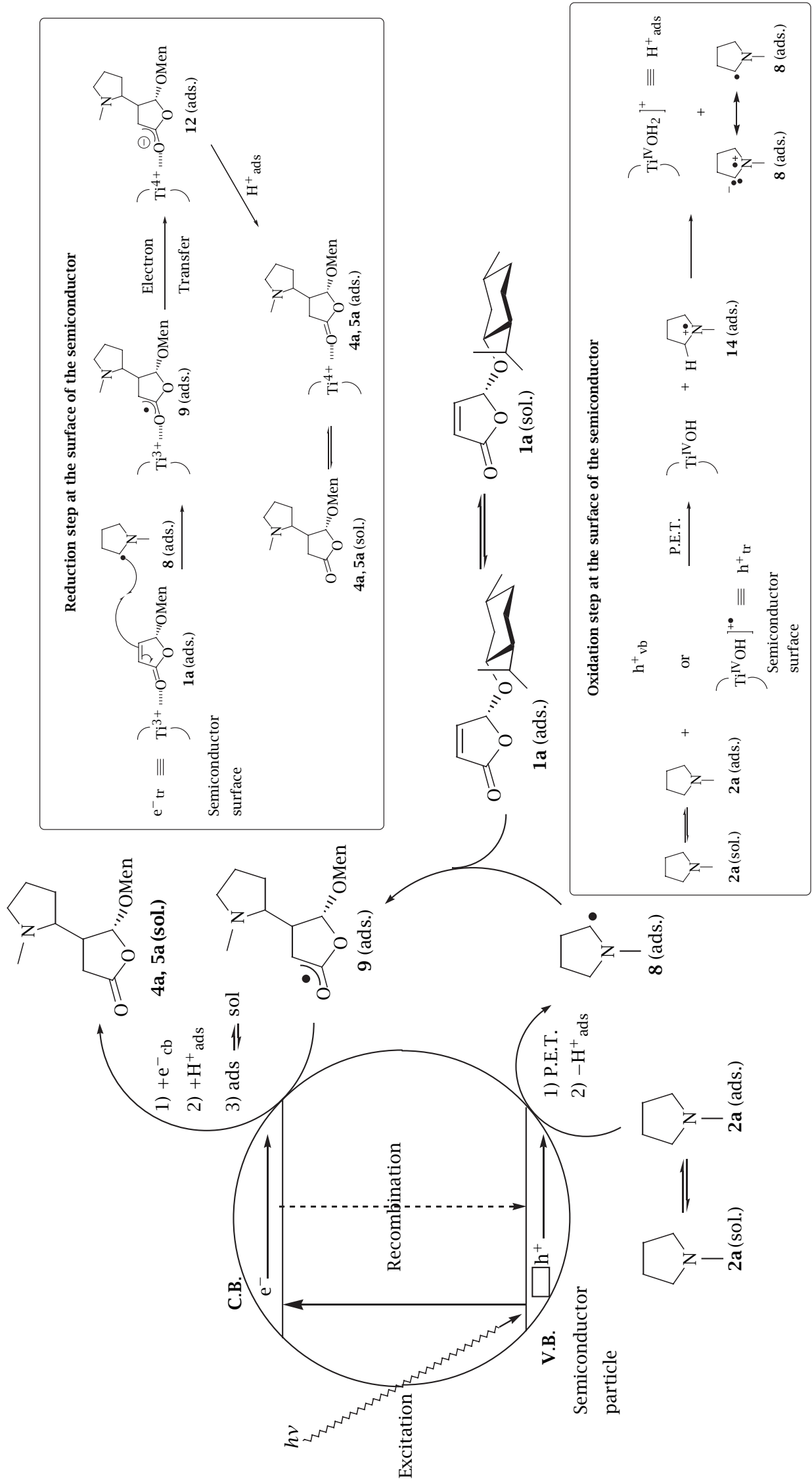

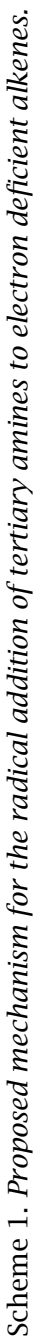


Table 4. Reaction of (5R)-menthyloxy-2[5H]furanone 1a with $N$-methylpiperidine 2c under different conditions.

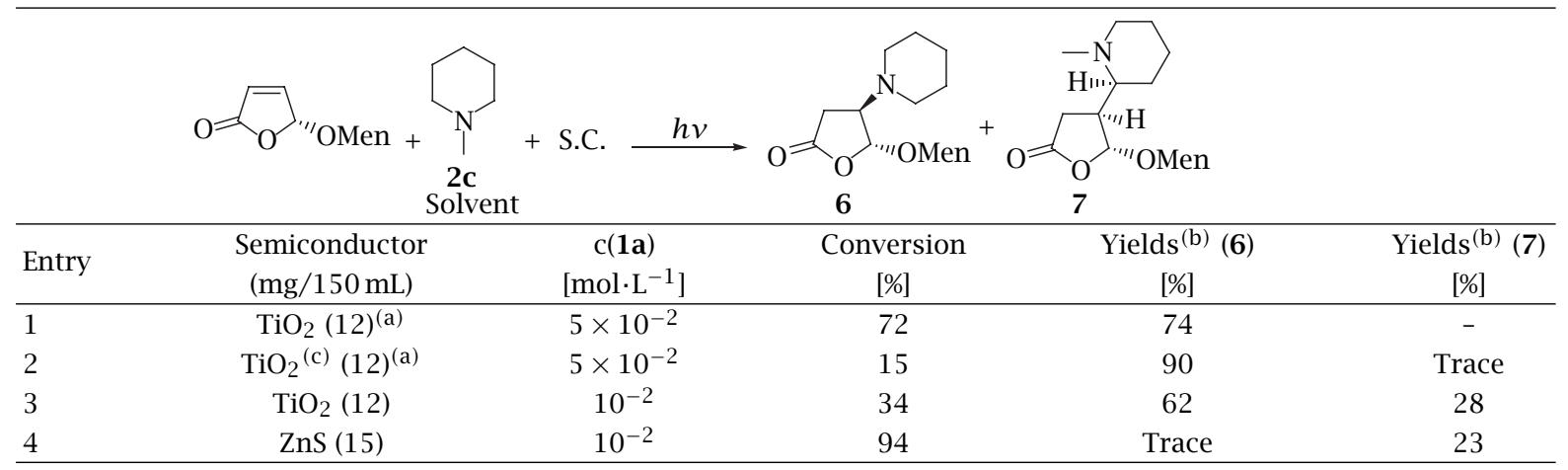

(a) The amount of semiconductor corresponds to 0.02 equivalent with respect to $1 \mathbf{a}$.

(b) Yields of isolated products and based on conversion of $\mathbf{1 a}$.

(c) The amine was distilled over $\mathrm{CaH}_{2}$ under argon and the semiconductor was kept at $100{ }^{\circ} \mathrm{C}$ for $48 \mathrm{~h}$.<smiles>CO[C@H]1OC(=O)CC1C1CC[C@H]([AlH])N1C</smiles><smiles>CO[C@H]1OC(=O)CC1C1CCC(C)N1C</smiles><smiles>CO[C@H]1OC(=O)C[C@@H]1C1CCC([TlH])N1C</smiles>

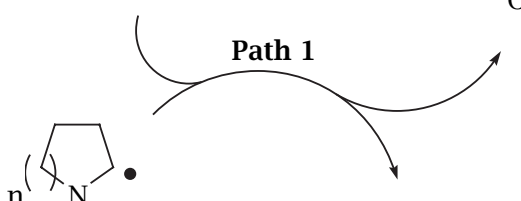

$\mathrm{n}=112$

$\mathrm{n}=213$

$\mathrm{n}=14 \mathrm{a}, 5 \mathrm{a}$

$\mathrm{n}=27$

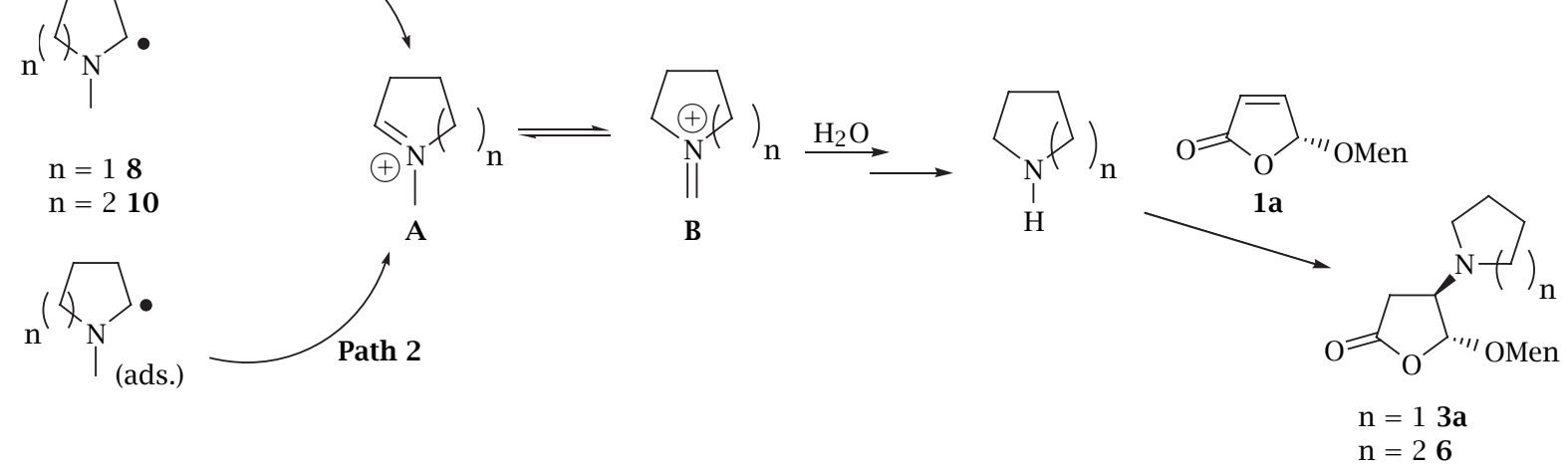

Scheme 2. Proposed mechanism for the oxidation of an $\alpha$-aminoalkyl radical by an oxoallyl radical or via a two electron oxidation at the surface of the semiconductor introducing the demethylation of $\mathbf{2 a}, \mathbf{c}$.

dispersion of the sensitiser $\left(\mathrm{TiO}_{2}\right.$ and $\left.\mathrm{ZnS}\right)$ could not be achieved and the coagulation of the semiconductor particles was observed.

\section{CONCLUSION}

Radical addition of tertiary amines to $\alpha, \beta$-unsatured lactones can be performed under heterogeneous conditions in high yields and high facial diastereoselectivity. According to these results and the proposed mechanism, the initiation and termination steps of the radical chain took place at the surface of the semiconductor via interfacial electron transfer. Side reaction of demethylation of the amines could be suppressed un- der optimized conditions. Furthermore, the heterogeneous photocatalysis is interesting from the ecological and economical point of view. No previous functionalization of the tertiary amines is necessary for $\mathrm{C}-\mathrm{C}$ bond formation. The amines are used both as reactant and as solvent, the excess is recycled by distillation and the inexpensive sensitiser can be easily removed by filtration.

\section{ACKNOWLEDGMENTS}

We thank Professor J. P. Pete for his support. S. M. thanks the Ministère de la Recherche for a doctoral fellowship. 


\section{EXPERIMENTAL SECTION}

1. General procedures. Irradiation of the suspensions were carried out with a Rayonet apparatus (model RPR-100) from the Southern New England Ultraviolet Compagny equipped with lamps emitting at $\lambda=$ $350 \mathrm{~nm}$ as the light source.

${ }^{1} \mathrm{H}-\mathrm{NMR}$ and ${ }^{13} \mathrm{C}$-NMR spectra were recorded with a Bruker AC250 (250 MHz and $62 \mathrm{MHz}$, respectively, coupling constants are reported in $\mathrm{Hz}$ ). Chemical shifts are reported in ppm relative to tetramethylsilane as internal standard. Infrared spectra were recorded with a MIDAC Prospect IR (FTIR). Mass spectra were recorded with a JEOL D-300. Optical rotations were measured with a Perkin-Elmer 241 Polarimeter. Preparative Chromatography was carried out with Merck art 9385 Kieselgel 60.

Commercial source of $\mathrm{TiO}_{2}$ : anatase 99\% (from ACROS), SiC (form Aldrich) and ZnS (from Prolabo) were used as sensitisers in heterogeneous photocatalysis. Under anhydrous conditions, amines $\mathbf{2 a}$ were distilled over $\mathrm{CaH}_{2}$ under argon and the semiconductor was kept at $100{ }^{\circ} \mathrm{C}$ for $48 \mathrm{~h}$.

2. Radical addition of tertiary amines to 1 (typical procedure). A degassed (with argon) suspension of substrate $1\left(7.5 \mathrm{mmol}, 5 \times 10^{-2} \mathrm{~mol} \cdot \mathrm{L}^{-1}\right)$ and the semiconductor $(0.15 \mathrm{mmol}, 0.02 \mathrm{eq})$ in $150 \mathrm{~mL}$ of the tertiary amine was irradiated in Pyrex-tubes (outside diameter: $4 \mathrm{~cm}$ ) under vigorous stirring with a magnetic stir bar. The mixture was filtered through Celite and the solvent was recycled by distillation under reduced pressure. The residue was purified by flash chromatography (silica gel, eluent: petroleum ether/ethyl acetate: 2/1).

(-)-(4S,5R)-5-menthyloxy-4-pyrrolidin-4,5-dihydrofuran-2(3H)-one (3a):

M.p. $134{ }^{\circ} \mathrm{C} . \mathrm{R}_{\mathrm{f}}=0.53$ (ethyl acetate/petroleum ether: 1/2). ${ }^{1} \mathrm{H}-\mathrm{NMR}\left(\mathrm{CDCl}_{3}\right): \delta=0.78(\mathrm{~d}, \mathrm{~J}=6.9 \mathrm{~Hz}, 3 \mathrm{H}), 0.88$ $(\mathrm{d}, \mathrm{J}=7.3 \mathrm{~Hz}, 3 \mathrm{H}), 0.94(\mathrm{~d}, \mathrm{~J}=6.9 \mathrm{~Hz}, 3 \mathrm{H}), 0.79-1.04(\mathrm{~m}$, $3 \mathrm{H}), 1.13-1.29$ (m, 2H), 1.59-1.73 (m, 2H), 1.80 (m, 4H), 1.98-2.19 (m, 2H), 2.48-2.62 (m, 5H), 2.77 (dd, J = 18.3, $7.6 \mathrm{~Hz}, 1 \mathrm{H}), 3.04$ (ddd, J = 7.6, 4.2, $1.4 \mathrm{~Hz}, 1 \mathrm{H}), 3.54$ (td, $\mathrm{J}=10.7,4.2 \mathrm{~Hz}, 1 \mathrm{H}), 5.60(\mathrm{~d}, \mathrm{~J}=1.4 \mathrm{~Hz}, 1 \mathrm{H}) .{ }^{13} \mathrm{C}-\mathrm{NMR}$ $\left(\mathrm{CDCl}_{3}\right): \delta=15.6,20.8,22.2,23.1,23.2,25.4,31.3$, 33.5, 34.2, 39.6, 47.7, 51.5, 65.5, 77.1, 102.9, 174.7. IR $(\mathrm{KBr}): v\left[\mathrm{~cm}^{-1}\right]=2960,1780,1460,1125,950,920 . \mathrm{MS}$ $(70 \mathrm{eV}): \mathrm{m} / \mathrm{z}(\%): 309(8)\left[\mathrm{M}^{+}\right], 170(8), 142(100), 126$ (15), $112(98) .\left[\alpha_{\mathrm{D}}\right]^{21}=-140.0,[\alpha]^{21}{ }_{578}=-140.0$, $[\alpha]^{21}{ }_{546}=-157.1,[\alpha]^{21}{ }_{436}=-258.6,[\alpha]^{21}{ }_{365}=-388.6$ $\left(\mathrm{c}=0.14, \mathrm{CH}_{2} \mathrm{Cl}_{2}\right) \cdot \mathrm{C}_{18} \mathrm{H}_{31} \mathrm{NO}_{3}(309.23)$ calcd. $\mathrm{C}: 67.79$, $\mathrm{H}: 10.32, \mathrm{~N}: 4.94$, found $\mathrm{C}: 68.17, \mathrm{H}: 10.02, \mathrm{~N}: 4.43$.

(-)-(4S,5R,2'S)-5-menthyloxy-4-(1'-methylpyrrolidin2'-yl)-4,5-dihydrofuran-2(3H)-one (4a):

M.p. $122^{\circ} \mathrm{C} . \mathrm{R}_{\mathrm{f}}=0.30$ (ethyl acetate/petroleum ether: 1/2). ${ }^{1} \mathrm{H}-\mathrm{NMR}\left(\mathrm{CDCl}_{3}\right): \delta=0.79(\mathrm{~d}, \mathrm{~J}=6.9 \mathrm{~Hz}, 3 \mathrm{H}), 0.89$ $(\mathrm{d}, \mathrm{J}=7.6 \mathrm{~Hz}, 3 \mathrm{H}), 0.94(\mathrm{~d}, \mathrm{~J}=6.9 \mathrm{~Hz}, 3 \mathrm{H}), 0.74-1.02(\mathrm{~m}$, 3H), 1.13-1.49 ((m, 4H)), 1.60-1.84 (m, 4H), 2.03-2.72 (m, 7H), 2.29 (s, 3H), $3.06(\mathrm{~m}, 1 \mathrm{H}), 3.54(\mathrm{td}, \mathrm{J}=10.7$,
$4.2 \mathrm{~Hz}, 1 \mathrm{H}), 5.40(\mathrm{~d}, \mathrm{~J}=1.5 \mathrm{~Hz}, 1 \mathrm{H}) .{ }^{13} \mathrm{C}-\mathrm{NMR}\left(\mathrm{CDCl}_{3}\right)$ : $\delta=15.6,20.9,22.2,22.4,23.1,25.4,25.9,28.8,31.3$, 34.3, 39.8, 40.5, 42.7, 47.7, 56.8, 65.4, 76.7, 103.0, 176.4 . IR $(\mathrm{KBr}): v\left[\mathrm{~cm}^{-1}\right]=2965,2865,1780,1455,1375$, 1240, 1160, 950. MS $(70 \mathrm{eV}): \mathrm{m} / \mathrm{z}(\%): 323(10)\left[\mathrm{M}^{+}\right]$, 322 (44), 184 (100), 170 (21), 135 (22), 110 (17). $\left[\alpha_{\mathrm{D}}\right]^{21}=-136.0,[\alpha]^{21}{ }_{578}=-140.7,[\alpha]^{21}{ }_{546}=-159.2$, $[\alpha]^{21}{ }_{436}=-261.4,[\alpha]^{21}{ }_{365}=-391.4\left(\mathrm{c}=0.98, \mathrm{CH}_{2} \mathrm{Cl}_{2}\right)$. $\mathrm{C}_{19} \mathrm{H}_{33} \mathrm{NO}_{3}$ (323.24) calcd. C: $70.53, \mathrm{H}: 10.29$, N: 4.33, found C: 70.11, H: 10.41, N: 4.46.

(-)-(4S,5R,2'R)-5-menthyloxy-4-(1'-methylpyrrolidin2'-yl)-4,5-dihydrofuran-2(3H)-one (5a):

M.p. $116^{\circ} \mathrm{C} . \mathrm{R}_{\mathrm{f}}=0.44$ (ethyl acetate/petroleum ether: 1/2). ${ }^{1} \mathrm{H}-\mathrm{NMR}\left(\mathrm{CDCl}_{3}\right): \delta=0.78(\mathrm{~d}, \mathrm{~J}=6.9 \mathrm{~Hz}, 3 \mathrm{H})$, 0.87 (d, J = 7.6 Hz, 3H), 0.94 (d, J = 6.9 Hz, 3H), 0.79$1.04(\mathrm{~m}, 3 \mathrm{H}), 1.11-1.58(\mathrm{~m}, 4 \mathrm{H}), 1.62-1.89(\mathrm{~m}, 4 \mathrm{H})$, 2.01-2.34 (m, 2H), $2.31(\mathrm{~s}, 3 \mathrm{H}), 2.50-2.61(\mathrm{~m}, 4 \mathrm{H})$, 2.80 (dd, J = 17.6, 10.5 Hz, 1H), 3.05 (m, 1H), 3.54 (td, $\mathrm{J}=10.7,4.2 \mathrm{~Hz}, 1 \mathrm{H}), 5.60$ (d, J = 1.9 Hz, $1 \mathrm{H}) .{ }^{13} \mathrm{C}-\mathrm{NMR}$ $\left(\mathrm{CDCl}_{3}\right): \delta=15.5,20.7,22.2,22.4,23.1,25.3,28.7$, 28.7, 31.1, 34.3, 39.7, 40.7, 42.8, 47.7, 57.0, 65.2, 77.1, 102.3, 176.4. IR (KBr): $v\left[\mathrm{~cm}^{-1}\right]=2935,2790$, 1785, 1460, 1370, 1250, 1165, 955. MS (70 eV): m/z(\%): $323(23)\left[\mathrm{M}^{+}\right], 322$ (100), 243 (45), 184 (76), 135 (83). $\left[\alpha_{\mathrm{D}}\right]^{21}=-123.0,[\alpha]^{21}{ }_{578}=-127.3,[\alpha]^{21}{ }_{546}=-143.4$, $[\alpha]^{21}{ }_{436}=-239.5,[\alpha]^{21}{ }_{365}=-361.2\left(\mathrm{c}=0.84, \mathrm{CH}_{2} \mathrm{Cl}_{2}\right)$. $\mathrm{C}_{19} \mathrm{H}_{33} \mathrm{NO}_{3}$ (323.24) calcd. C: 70.53, H: 10.29, N: 4.33, found C: 70.30, H: 10.08, N: 4.39.

(-)-(4S,5R)-5-menthyloxy-4-piperidin-4,5-dihydrofuran-2(3H)-one (6):

M.p. $119^{\circ} \mathrm{C} . \mathrm{R}_{\mathrm{f}}=0.63$ (ethyl acetate/petroleum ether: 1/2). ${ }^{1} \mathrm{H}-\mathrm{NMR}\left(\mathrm{CDCl}_{3}\right): \delta=0.75(\mathrm{~d}, \mathrm{~J}=6.7 \mathrm{~Hz}, 3 \mathrm{H})$, $0.86(\mathrm{~d}, \mathrm{~J}=7.0 \mathrm{~Hz}, 3 \mathrm{H}), 0.93(\mathrm{~d}, \mathrm{~J}=6.6 \mathrm{~Hz}, 3 \mathrm{H}), 0.77-$ $1.10(\mathrm{~m}, 3 \mathrm{H}), 1.13-1.27$ (m, 1H), 1.29-1.53 (m, 9H), 1.93-2.13 (m, 1H), 2.04-2.19 (m, 1H), 2.33-2.58 (m, 5H), 2.75 (dd, J = 18.1, 8.3 Hz, 1H), 3.04 (m, 1H), 3.52 $(\mathrm{td}, \mathrm{J}=10.6,4.2 \mathrm{~Hz}, 1 \mathrm{H}), 5.60(\mathrm{~d}, \mathrm{~J}=1.6 \mathrm{~Hz}, 1 \mathrm{H})$. ${ }^{13} \mathrm{C}-\mathrm{NMR}\left(\mathrm{CDCl}_{3}\right): \delta=15.5,20.8,22.2,23.0,24.1$, 25.4, 25.8, 25.8, 31.2, 31.3, 34.2, 39.6, 47.7, 50.6, 50.6, $66.6,76.9,101.6,175.4$. IR $(\mathrm{KBr}): v\left[\mathrm{~cm}^{-1}\right]=2953$, 1793, 1462, 1180, 1110, 948. MS (70 eV): m/z(\%): 323 (8) [ $\left.\mathrm{M}^{+}\right], 279$ (91), 156 (25), 140 (32), 126 (18), 111 (100). $\left[\alpha_{\mathrm{D}}\right]^{21}=-149.4,[\alpha]^{21}{ }_{578}=-154.9,[\alpha]^{21}{ }_{546}=-176.2$, $[\alpha]^{21}{ }_{436}=-259.3,[\alpha]^{21}{ }_{365}=-451.9\left(\mathrm{c}=1.04, \mathrm{CH}_{2} \mathrm{Cl}_{2}\right)$. $\mathrm{C}_{19} \mathrm{H}_{33} \mathrm{NO}_{3}$ (323.25) calcd. C: 70.55, H: 10.28, N: 4.33, found C: $70.47, \mathrm{H}: 10.05, \mathrm{~N}: 4.48$.

(-)-(4S,5R,2'S)-5-menthyloxy-4-(1-methylpiperidin2'-yl)-4,5-dihydrofuran-2(3H)-one (7):

M.p. $132{ }^{\circ} \mathrm{C} . \mathrm{R}_{\mathrm{f}}=0.40$ (ethyl acetate/petroleum ether: 1/2). ${ }^{1} \mathrm{H}-\mathrm{NMR}\left(\mathrm{CDCl}_{3}\right): \delta=0.78(\mathrm{~d}, \mathrm{~J}=6.9 \mathrm{~Hz}, 3 \mathrm{H}), 0.88$ $(\mathrm{d}, \mathrm{J}=6.9 \mathrm{~Hz}, 3 \mathrm{H}), 0.94(\mathrm{~d}, \mathrm{~J}=6.5 \mathrm{~Hz}, 3 \mathrm{H}), 0.74-1.07$ (m, $3 \mathrm{H}), 1.10-1.32(\mathrm{~m}, 3 \mathrm{H}), 1.33-1.60(\mathrm{~m}, 4 \mathrm{H}), 1.61-1.73(\mathrm{~m}$, 2H), 1.74-1.81 (m, 1H), 2.01-2.28 (m, 2H), 2.06 (dsep, $\mathrm{J}=6.9,2.4 \mathrm{~Hz}, 1 \mathrm{H}), 2.17(\mathrm{td}, \mathrm{J}=11.5,3.3 \mathrm{~Hz}, 1 \mathrm{H}), 2.22$ (s, 3H), 2.56 (dd, J = 18.2, 3.2 Hz, 1H), 2.64 (dd, J = 18.2, $9.0 \mathrm{~Hz}, 1 \mathrm{H}), 2.71-2.77$ (m, 1H), 2.88 (d, J = 11.7 Hz, 1H), 
$3.51(\mathrm{td}, \mathrm{J}=10.7,4.2 \mathrm{~Hz}, 1 \mathrm{H}), 5.43(\mathrm{~d}, \mathrm{~J}=0.8 \mathrm{~Hz}, 1 \mathrm{H})$.

${ }^{13} \mathrm{C}$-NMR $\left(\mathrm{CDCl}_{3}\right): \delta=15.6,20.9,22.2,23.1,24.1,24.6$, 24.9, 25.5, 28.2, 31.4, 34.3, 39.8, 42.2, 42.8, 47.8, 56.9, $63.3,76.5,102.3,176.9$. IR $(\mathrm{KBr}): v\left[\mathrm{~cm}^{-1}\right]=2930$, 2865, 1785, 1455, 1370, 1165, 940. MS (70 eV): m/z(\%): 337 (1.5) [ $\left.\mathrm{M}^{+}\right], 322$ (0.2), 238 (0.3), 198 (100), 124 (7). $\left[\alpha_{\mathrm{D}}\right]^{21}=-116.2,[\alpha]^{21}{ }_{578}=-120.3,[\alpha]^{21}{ }_{546}=-142.8$, $[\alpha]^{21}{ }_{436}=-236.4,[\alpha]^{21}{ }_{365}=-249.6\left(\mathrm{c}=0.84, \mathrm{CH}_{2} \mathrm{Cl}_{2}\right)$. $\mathrm{C}_{20} \mathrm{H}_{35} \mathrm{NO}_{3}$ (337.50) calcd. C: 71.18, H: 10.45, N: 4.15, found C: 70.91, H: 10.18, N: 3.99 .

\section{REFERENCES}

[1] (a) B. Giese, Radicals in Organic Synthesis: Formation of Carbon-Carbon Bonds, Pergamon Press, Oxford, 1986.

(b) J. Fossey, D. Lefort, and J. Sorba, Free Radicals in Organic Chemistry, Wiley, Chichester, 1995.

(c) D. P. Curran, N. A. Porter, and B. Giese, Setreochemistry of Radical Reactions, VCH, Weinheim, 1996.

[2] P. Renaud and L. Giraud, Synthesis (1996), 913.

[3] (a) E. Santiago de Alvarenga, C. J. Cardin, and J. Mann, Tetrahedron 53 (1997), 1457.

(b) E. Santiago de Alvarenga and J. Mann, J. Chem. Soc. Perkin Trans. 1 (1993), 2141.

(c) E. Farrant and J. Mann, J. Chem. Soc. Perkin Trans. 1 (1997), 1083.

[4] (a) R. C. Cookson, J. Hudec, and N. A. Mirza, Chem. Commun. (1968), 180.

(b) R. C. Cookson, S. M. de B. Costa, and J. Hudec, Chem. Commun. (1969), 753.

[5] W. H. Urry and O. O. Juveland, J. Am. Chem. Soc. 80 (1958), 3322.

[6] (a) S. Bertrand, C. Glapsky, N. Hoffmann, and J. P. Pete, Tetrahedron Lett. 40 (1999), 3169.

(b) S. Bertrand, N. Hoffmann, and J. P. Pete, Tetrahedron Lett. 40 (1999), 3173.

[7] S. Bertrand, N. Hoffmann, and J. P. Pete, Eur. J. Org. Chem. (2000), 2227.

[8] (a) S. Bertrand, N. Hoffmann, J. P. Pete, and V. Bulach, Chem. Commun. (1999), 2291.

(b) S. Bertrand, N. Hoffmann, S. Humbel, and J. P. Pete, J. Org. Chem. 65 (2000), 8690.

[9] O. Legrini, E. Oliveros, and A. M. Braun, Chem. Rev. 93 (1993), 671.

[10] M. R. Hoffmann, S. T. Martin, W. Choi, and D. W. Bahnemann, Chem. Rev. 95 (1995), 69.

[11] M. Grätzel, Photoinduced electron transfer, Part D, (M. A. Fox and M. Chanon, Eds.), Elsevier, Amsterdam, 1988, Chapter 6.3.

[12] (a) M. A. Fox and M. T. Dulay, Chem. Rev. 93 (1993), 341.

(b) P. Pichat, Catal. Today 19 (1994), 313.

(c) Y. Li, V. Ramamurthy, and K. S. Schanze, (Eds.), Organic Photochemistry, Marcel Dekker Inc., New York, 1997, p. 295.

(d) M. A. Fox, Electron Transfer in Chemistry
(V. Balzani, Ed.), Vol. 1, Part 1 (P. Piotrowiak, Ed.), Wiley-VCH, Weinheim, 2001, p. 271.

[13] (a) L. Cermenati, C. Richter, and A. Albini, Chem. Commun. (1998), 805.

(b) R. Künneth, C. Feldmer, F. Knoch, and H. Kisch, Chem. Eur. J. 1 (1995), 441.

(c) W. Schindler, F. Knoch, and H. Kisch, Chem. Ber. 129 (1996), 925.

(d) H. Keck, W. Schindler, F. Knoch, and H. Kisch, Chem. Eur. J. 3 (1997), 1638.

(e) G. Höner, P. Johne, R. Künneth, G. Twardzik, H. Roth, T. Clark, and H. Kisch, Chem. Eur. J. 5 (1999), 208.

[14] S. Marinković and N. Hoffmann, Chem. Commun. (2001), 1576.

[15] P. Pichat and M. A. Fox, Photoinduced electron transfer, Part D, (M. A. Fox and M. Chanon, Eds.), Elsevier, Amsterdam, 1988, Chapter 6.1.

[16] A. Hagfeldt and M. Grätzel, Chem. Rev. 95 (1995), 49.

[17] (a) A. L. Linsebigler, G. Lu, and J. T. Yates, Jr., Chem. Rev. 95 (1995), 735.

(b) P. V. Kamat, Chem. Rev. 93 (1993), 267.

[18] (a) T. I. Ho and F. D. Lewis, J. Am. Chem. Soc. 102 (1980), 1751.

(b) F. D. Lewis, Acc. Chem. Res. 19 (1986), 401.

[19] (a) G. W. Dombrowski, J. P. Dinnocenzo, S. Farid, J. L. Goodman, and I. R. Gould, J. Org. Chem. 64 (1999), 427.

(b) D. D. M. Wayner, K. B. Clark, A. Rauk, D. $\mathrm{Yu}$, and D. A. Armstrong, J. Am. Chem. Soc. 119 (1997), 8925.

(c) J. D. Scott and R. M. Williams, Chem. Rev. 102 (2002), 1669.

[20] M. Schmittel and A. Burghart, Angew. Chem. Int. Ed. Engl. 36 (1997), 2550.

[21] (a) C. Ferroud, P. Rool, and J. Santamaria, Tetrahedron Lett. 39 (1998), 9423.

(b) G. Pandey, G. Kumaraswamy, and P. Y. Reddy, Tetrahedron 48 (1992), 8295.

(c) G. Pandey, Synlett (1992), 546.

(d) J. Cossy and M. Guha, Tetrahedron Lett. 35 (1994), 1715.

(e) X. Zhang, Y. S. Jung, P. S. Mariano, M. A. Fox, P. S. Martin, and J. Merkert, Tetrahedron Lett. 34 (1993), 5239.

(f) M. Bietti, A. Cuppoletti, C. Dagostin, C. Florea, C. Galli, P. Gentili, H. Petride, and R. Caia, Eur. J. Org. Chem. (1998), 2425.

[22] B. de Lange, F. van Bolhuis, and B. L. Feringa, Tetrahedron 45 (1989), 6799.

[23] (a) S. Yanagida, A. Takayuki, K. Horishi, K. Hirotoshi, and S. Hiroshi, J.C.S. Chem. Commun. (1984), 21.

(b) H. Kisch and M. Hopfner, Electron Transfer in Chemistry (V. Balzani, Ed.), Vol. 4, Part 1 (S. Fukuzumi, Ed.), Wiley-VCH, Weinheim, 2001, p. 232. 


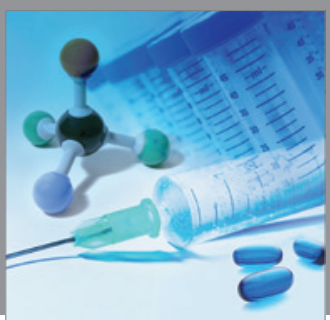

International Journal of

Medicinal Chemistry

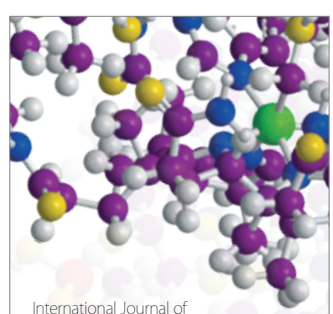

Carbohydrate Chemistry

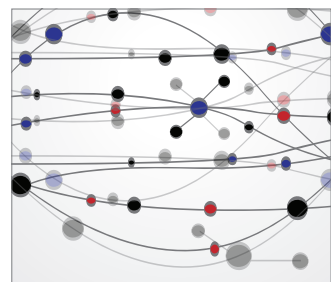

The Scientific World Journal
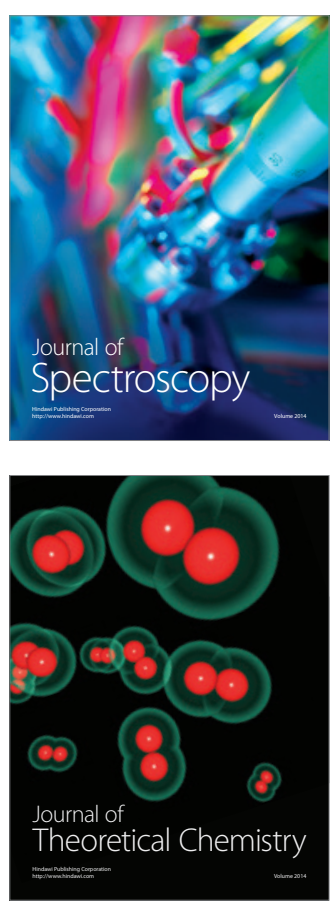
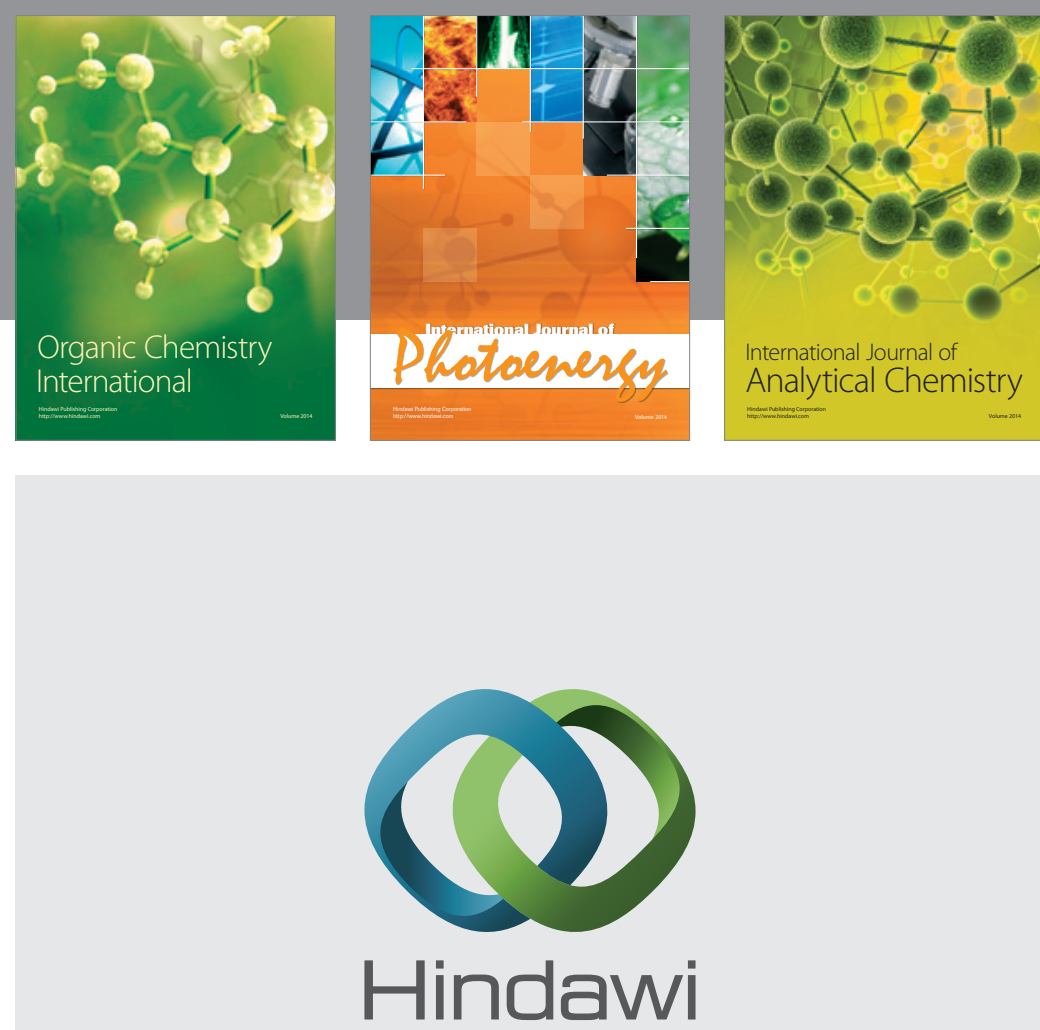

Submit your manuscripts at

http://www.hindawi.com
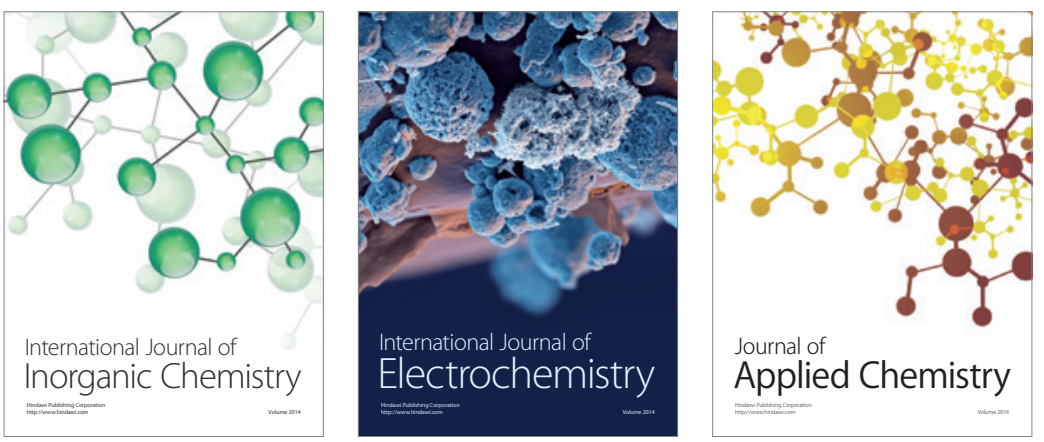

Journal of

Applied Chemistry
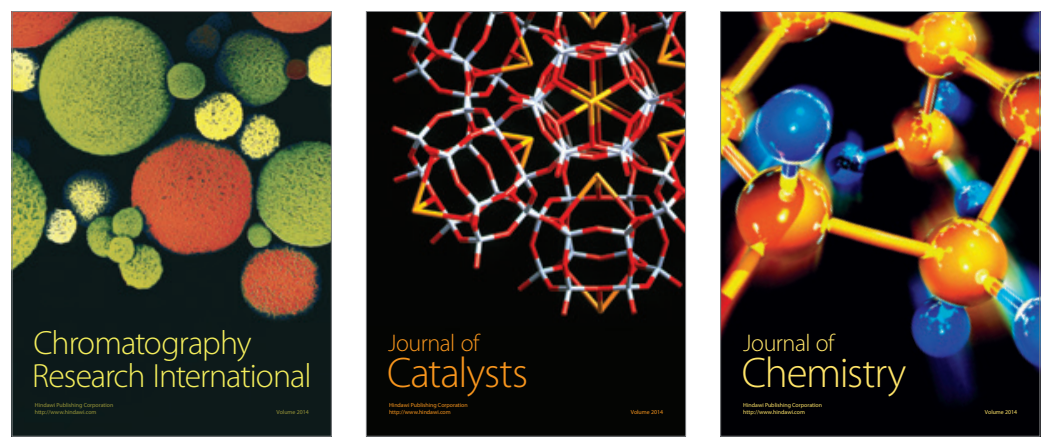
